\title{
EVALUATION OF THE ANTIOXIDANT POTENTIAL OF CAPSICUM ANNUUM L., C. BACCATUM L. AND C. CHINENSE JACQ. CULTIVARS
}

\author{
Erika Mňahončáková ${ }^{1}$, Olena Vergun², Olga Grygorieva ${ }^{2 凶}$, \\ Vladimíra Horčinová Sedláčková3 , Eva Ivanišová4 , Katarína Fatrcová Šramková5, \\ Michaela Hrúzová ${ }^{1}$, Ján Brindza ${ }^{3}$
}

${ }^{1}$ Botanical Garden, Slovak University of Agriculture in Nitra

Tr. A. Hlinku 2, 94976 Nitra, Slovakia

${ }^{2}$ M. M. Gryshko National Botanical Garden of Ukraine of National Academy of Sciences

Timiryazevska 1, 01014 Kyiv, Ukraine

${ }^{3}$ Institute of Biological Conservation and Biosafety, Slovak University of Agriculture in Nitra

Tr. A. Hlinku 2, 94976 Nitra, Slovakia

${ }^{4}$ Department of Technology and Quality of Plant Products, Slovak University of Agriculture in Nitra

Tr. A. Hlinku 2, 94976 Nitra, Slovakia

${ }^{5}$ Department of Human Nutrition, Slovak University of Agriculture in Nitra

Tr. A. Hlinku 2, 94976 Nitra, Slovakia

\begin{abstract}
Background. Economically important vegetables are a strong source of antioxidants with different characteristics. Capsicum L. (pepper) is an important agricultural plant because of its economical, medicinal, and nutritional values.

Materials and methods. This study aimed to test antioxidant parameters in the fruits of 9 cultivars of Capsicum annuum L. (CA 01-09), 7 cultivars of C. baccatum L. (CB 01-07), and 11 cultivars of $C$. chinense Jacq. (CC 01-11). The antioxidant activity of the investigated Capsicum cultivars was measured, along with the free radical scavenging activity (FRSA), using the DPPH method, and the molybdenum reducing power (MRP) was expressed as mg TE (Trolox equivalent) per g of DW (dry weight). Total polyphenol content (TPC), expressed as mg GAE (gallic acid equivalent) per g of DW, total flavonoid content (TFC), expressed as mg QE (quercetin equivalent) per g of DW, and total phenolic acid content (TPAC), expressed as mg CAE (caffeic acid equivalent) per $\mathrm{g}$ of DW, were the basic antioxidant parameters of antioxidant activity in this study. Results. All investigated Capsicum extracts exhibited FRSA from 1.45 (CC-06) to 8.21 (CC-05) mg TE/g and MRP from 24.84 (CA-06) to 198.21 (CB-07) $\mathrm{mg} \mathrm{TE} / \mathrm{g}$. The TPC of the tested extracts ranged from 10.13 (CB-03) to 38.68 (CB-07) mg GAE/g. The TFC of the studied samples showed values from 5.73 (CB-03) to 27.32 (CB-07) mg QE/g and TPAC from 2.24 (CB-03) to 13.07 (CC-07) mg CAE/g. A very strong correlation was found in the investigated cultivars between TPC and TPAC ( $r=0.932,0.839$ and 0.848 , respectively), and between TPC and TFC ( $r=0.921,0.982$ and 0.939 , respectively). Very strong relations were also found between TPC and FRSA $(r=0.820)$ in the $C$. annuum cultivars and between TPC and MRP $(r=0.898)$ in the C. baccatum cultivars.

Conclusion. This study found useful results concerning the antioxidant potential of the fruits of Capsicum cultivars. The data obtained demonstrate the strong antioxidant activity of cultivars of Capsicum, which can be used in the food industry because of the commercial importance of these fruits.
\end{abstract}

Keywords: Capsicum spp., cultivars, antioxidant activity, phenolic compounds

\footnotetext{
®olgrygorieva@gmail.com
} 


\section{INTRODUCTION}

Capsicum L. (pepper) is an important agricultural plant because of its economical, medicinal, and nutritional values. These plants have been used for centuries as a colourant, flavourant, and pungency source, and can be used fermented as well as fresh and dried (Nadeem et al., 2011). Capsicum annuum L. has a beneficial effect on metabolic processes in the human organism and can decrease the risk of cardiovascular diseases (Sanati et al., 2018). The fruit of Capsicum spp. are a functional food that can be used in the prevention of diabetes mellitus and obesity (Tundis et al., 2011).

The fruit of green, red and yellow pepper (Capsicum L.) contain numerous biologically active compounds such as carotenoids, phenols, $B$-carotene (Antonious et al., 2009), alkaloids, and vitamins (vitamin A, C, E) (Batra et al., 2017), which possess an antioxidant capacity. Perucka and Materska (2007) determined the content of ascorbic acid to be from 101.19 to $167.54 \mathrm{mg}$ per $100 \mathrm{~g}$ and $B$-carotene to be from 0.058 to $0.460 \mathrm{mg}$ per $100 \mathrm{~g}$ of fresh weight (FW). In a study by Medina-Juárez et al. (2012), the ascorbic acid content was 121.14-251.60 mg per $100 \mathrm{~g} \mathrm{FW}$. This parameter, as reported by Kantar et al. (2016), in 90 analyzed species of peppers ranged from 11.9 to $195.8 \mathrm{mg}$ per $100 \mathrm{~g}$. Aliu et al. (2017) identified the vitamin $C$ content to be from 65.54 to $520.51 \mathrm{mg}$ per $100 \mathrm{~g}$ of fresh weight.

Among carotenoids, the fruit of Capsicum spp. have xanthophylls, violaxanthin, neoxanthin, and lutein, etc. (Minguez-Mosquera and Hornero-Mendez, 1994; Rodríguez-Burruezo et al., 2010). In yellow-orange chili peppers (Capsicum annuum), violaxanthin is the major carotenoid (37-68\%), followed by antheraxanthin, and lutein (5-14\%), while in red Capsicum annuum, it is ketoxanthophylls, followed by xanthophylls, epoxyxanthophylls, and hydrocarbons (Gomez-García and Ochoa-Alejo, 2013). Also, the carotenoids of $C$. annuum exhibit antioxidant and antiinflammatory effects (Hernández-Ortega et al., 2012).

A study of mineral composition showed that unripe cultivars accumulated more phosphorus, potassium, calcium, and fully ripe cultivars accumulated more magnesium and iron (Ribes-Moya et al., 2014).

Hot sensory tests of these plants are caused by the presence of capsaicinoids, which is the major group of organic compounds (alkaloids) that are used in the pharmaceutical industry due to their neurological effects. The major capsaicinoids, capsaicin and dihydrocapsaicin, are responsible for the pungency of this species (Antonious et al., 2009). The highest content of capsaicinoids accumulates in the pericarp (65-85\%), as investigated by Guillen et al. (2018). Wesołowska et al. (2011) investigated the biochemical composition of acetone extracts and determined capsaicin content in two cultivars of $C$. annuum to be 37.22 and $40.85 \%$.

A study of the content of different compounds such as phenols, flavonoids, and capsaicinoids, etc. showed that fresh peppers contain a higher content of them than processed ones (Loizzo et al., 2015). A study of extracts of Capsicum fruits and seeds exhibited antioxidant, hypoglycaemic (Tundis et al., 2011), and anti-inflammatory properties (Zimmer et al., 2012). Both extracts of $C$. annuum and $C$. frutescens were identified to be effective against Vibrio cholerae, Staphylococcus aureus, and Salmonella typhimurium, etc. (Koffi-Nevry et al., 2012).

The objective of this study was to evaluate the antioxidant activity, as well as the total polyphenol, flavonoid, and phenolic acid contents in cultivars of an experimental collection of Capsicum species.

\section{MATERIALS AND METHODS}

\section{Biological materials}

Fruits of cultivars of Capsicum annuum L. (Black Cobra, Kilian, Pepperoncini Greek, Tabasco, Jalapeno, Black Prince, Chocho, Medusa, Habanero Red, marked as CA-01 - CA-09, respectively), C. baccatum L. (Escabeche, Bishops Crown Red, Aji Fantasy Sparkly White, Aji Amarillo, Puerto Rican, El Oro de Ecuador, Habanero Red Savina, marked as CB-01 - CB-07, respectively), and $C$. chinense Jacq. (Aji Charapita, Habanero Peach, Trinidad Scorpion Peach, Jolokia White, Fidalgo Roxa, Habanero Chocolate, Fatalii Red, Peter Orange, Red Mushroom, Citron, Pimenta de Neyde, marked as CC-01 - CC-11, respectively) were used in this study (Fig. 1, 2 and 3). All 27 cultivars of Capsicum that were the subject of the study were grown in greenhouse conditions in the botanical garden located on the grounds of the Slovak University of Agriculture in Nitra (Mňahončáková et al., 2020). The investigated fruits were oven dried at $55^{\circ} \mathrm{C}$ for $30 \mathrm{~h}$ and milled to a powder (Kim et al., 2019). 
Mňahončáková, E., Vergun, O., Grygorieva, O., Sedláčková, V. H., Ivanišová, E., Šramková, K. F., Hrúzová, M., Brindza, J. (2021). Evaluation of the antioxidant potential of Capsicum annuum L., C. baccatum L. and C. chinense Jacq. cultivars. Acta Sci. Pol. Technol. Aliment., 20(2), 223-236. http://dx.doi.org/10.17306/J.AFS.2021.0941

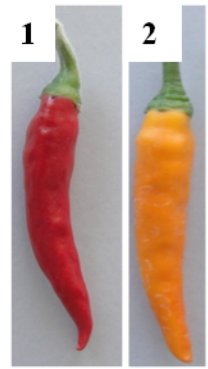

6

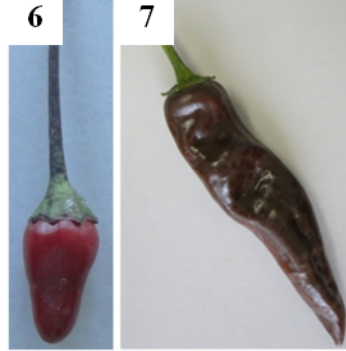

8

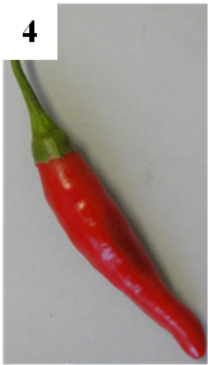

9
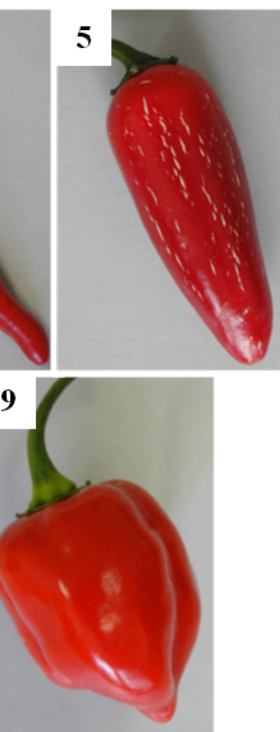

Fig. 1. Cultivars of Capsicum annuum L.: 1 - Black Cobra, 2 Kilian, 3 - Pepperoncini Greek, 4 - Tabasco, 5 - Jalapeno, 6 Black Prince, 7 - Chocho, 8 - Medusa, 9 - Habanero Red
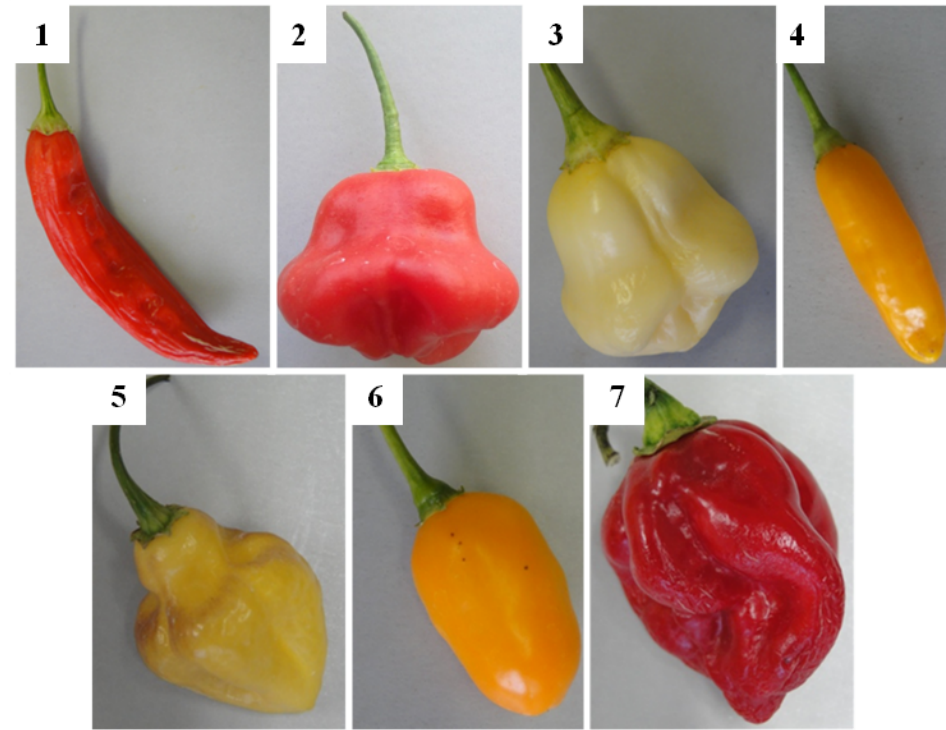

Fig. 2. Cultivars of Capsicum baccatum L.: 1 - Escabeche, 2 - Bishops Crown Red, 3 - Aji Fantasy Sparkly White, 4 -Aji Amarillo, 5 - Puerto Rican, 6 - El Oro de Ecuador, 7 - Habanero Red Savina

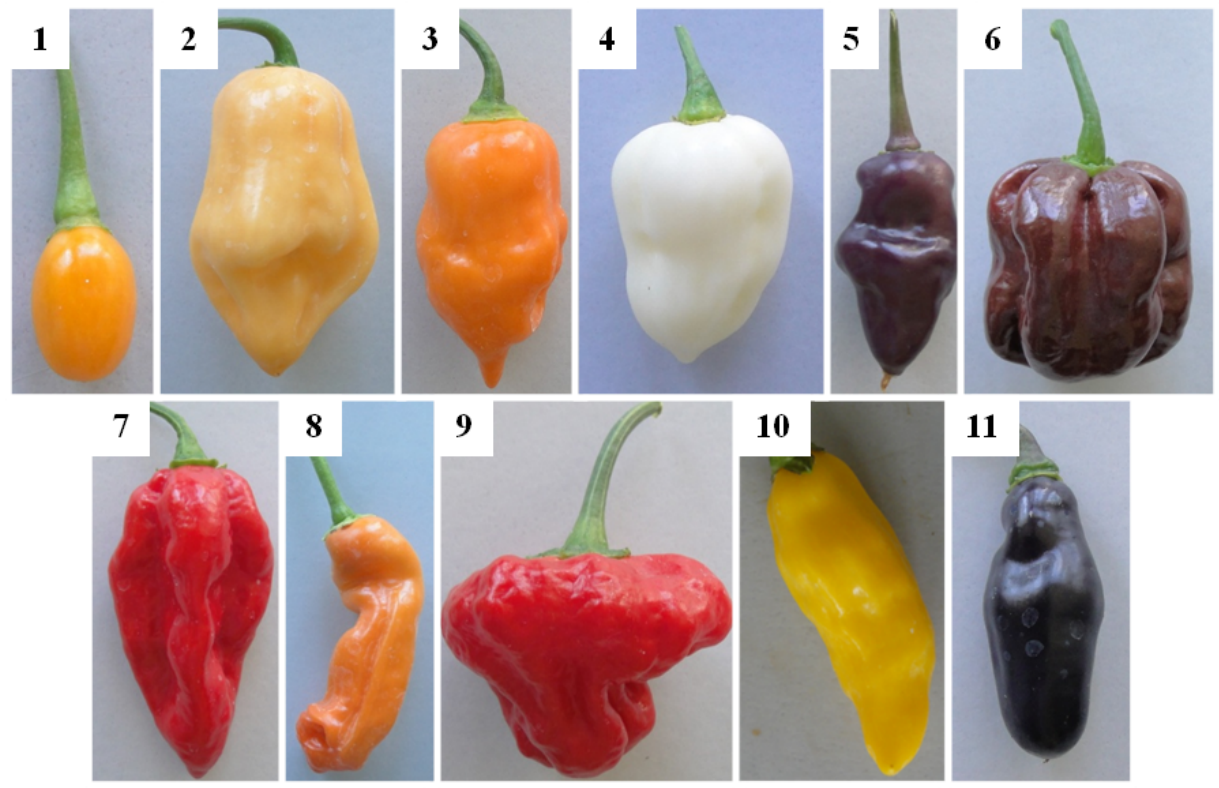

Fig. 3. Cultivars of Capsicum chinense Jacq.: 1 - Aji Charapita, 2 - Habanero Peach, 3 - Trinidad Scorpion Peach, 4 - Jolokia White, 5 - Fidalgo Roxa, 6 - Habanero Chocolate, 7 - Fatalii Red, 8 - Peter Orange, 9 - Red Mushroom, 10 - Citron, 11 - Pimenta de Neyde 


\section{Chemicals}

All chemicals used were of analytical grade and were purchased from Sigma-Aldrich (St. Louis, MO, USA) and CentralChem (Slovakia).

\section{Preparation of sample extracts}

An amount of $0.25 \mathrm{~g}$ of each sample was extracted with $20 \mathrm{~mL}$ of $80 \%$ ethanol for $2 \mathrm{~h}$ in a laboratory shaker GFL 3005 (GFL, Burgwedel, Germany). Then the samples were centrifuged at $4605 \mathrm{RCF}$ (Rotofix 32 A, Hettich, Germany) for 10 min and the supernatant was used to measure FRSA (antiradical activity) using the DPPH method, MRAP (antioxidant activity) using the phosphomolybdenum method, and other antioxidant properties (detection of total polyphenol, total flavonoid, and phenolic acid content).

\section{Free radical scavenging activity - DPPH method}

The free radical scavenging activity (FRSA) of the samples (antiradical activity) was measured using the 2,2-diphenyl-1-picrylhydrazyl (DPPH) (Sánchéz-Moreno et al., 1998). An amount of $0.4 \mathrm{~mL}$ of sample was mixed with $3.6 \mathrm{~mL}$ of DPPH solution $(0.025 \mathrm{~g}$ DPPH in $100 \mathrm{~mL}$ ethanol). The absorbance of the reaction mixture was determined with a spectrophotometer Jenway (6405 UV/Vis, England) at $515 \mathrm{~nm}$. Trolox (6-hydroxy-2,5,7,8-tetramethylchroman-2-carboxylic acid) $\left(10-100 \mathrm{mg} / \mathrm{L} ; R^{2}=0.989\right)$ was used as the standard and the results were expressed in $\mathrm{mg} / \mathrm{g}$ DM Trolox equivalents.

\section{Molybdenum reducing power}

The molybdenum reducing power (MRP) of the samples was determined using the method of Prieto et al. (1999) with slight modifications. A mixture of the sample $(1 \mathrm{~mL})$, monopotassium phosphate $(2.8 \mathrm{~mL}, 0.1 \mathrm{M})$, sulfuric acid $(6 \mathrm{~mL}, 1 \mathrm{M})$, ammonium heptamolybdate $(0.4 \mathrm{~mL}, 0.1 \mathrm{M})$, and distilled water $(0.8 \mathrm{~mL})$ was incubated at $90^{\circ} \mathrm{C}$ for $120 \mathrm{~min}$, then cooled to room temperature. The absorbance at $700 \mathrm{~nm}$ was detected with a spectrophotometer Jenway (6405 UV/Vis, England). Trolox (10-1000 mg/L; $\left.R^{2}=0.998\right)$ was used as the standard and the results were expressed in $\mathrm{mg} / \mathrm{g}$ DM Trolox equivalent.

\section{Total polyphenol content}

The total polyphenol content (TPC) was measured using the method of Singleton and Rossi (1965) using a Folin-Ciocalteu reagent. A quantity of $0.1 \mathrm{~mL}$ of each sample was mixed with $0.1 \mathrm{~mL}$ of the Folin-Ciocalteu reagent, $1 \mathrm{~mL}$ of $20 \%(\mathrm{w} / \mathrm{v})$ sodium carbonate, and $8.8 \mathrm{~mL}$ of distilled water. After $30 \mathrm{~min}$ in darkness, the absorbance at $700 \mathrm{~nm}$ was measured with a spectrophotometer Jenway (6405 UV/Vis, England). Gallic acid $\left(25-300 \mathrm{mg} / \mathrm{L} ; R^{2}=0.998\right)$ was used as the standard. The results were expressed in $\mathrm{mg} / \mathrm{g}$ DW gallic acid equivalent.

\section{Total flavonoid content}

The total flavonoid content (TFC) was determined using the modified method described by Shafii et al. (2017). An aliquot of $0.5 \mathrm{~mL}$ of the sample was mixed with $0.1 \mathrm{~mL}$ of $10 \%(\mathrm{w} / \mathrm{v})$ ethanolic solution of aluminium chloride, $0.1 \mathrm{~mL}$ of $1 \mathrm{M}$ potassium acetate, and $4.3 \mathrm{~mL}$ of distilled water. After $30 \mathrm{~min}$ in darkness, the absorbance at $415 \mathrm{~nm}$ was measured using a spectrophotometer Jenway (6405 UV/Vis, England). Quercetin $\left(1-400 \mathrm{mg} / \mathrm{L} ; R^{2}=0.9977\right)$ was used as the standard. The results were expressed in $\mathrm{mg} / \mathrm{g} \mathrm{DW}$ quercetin equivalent.

\section{Total phenolic acid content}

The total phenolic acid content (TPAC) was determined using the method of Farmakopea Polska (1999). $0.5 \mathrm{~mL}$ of the sample was mixed with $0.5 \mathrm{~mL}$ of $0.5 \mathrm{M}$ hydrochloric acid, $0.5 \mathrm{~mL}$ of Arnov's reagent, $0.5 \mathrm{~mL}$ of $1 \mathrm{M}$ sodium hydroxide $(\mathrm{w} / \mathrm{v})$ and $0.5 \mathrm{~mL}$ of water. Absorbance at $490 \mathrm{~nm}$ was measured using a spectrophotometer Jenway (6405 UV/Vis, England). Caffeic acid $\left(1-200 \mathrm{mg} / \mathrm{L}, R^{2}=0.999\right)$ was used as the standard and the results were expressed in $\mathrm{mg} / \mathrm{g}$ DW caffeic acid equivalents.

\section{Statistical analysis}

Basic statistical analyses were performed using PAST 2.17; the results are expressed as mean values of three replications \pm standard deviation (SD); hierarchical cluster analyses of similarity between phenotypes were computed on the basis of the Bray-Curtis similarity index. The data were analysed using the ANOVA test and differences between means compared through the Tukey-Kramer test $(P<0.05)$. 


\section{RESULTS AND DISCUSSION}

As has been shown in numerous studies, antioxidants have become a topic of increasing interest in recent times because of their beneficial role in human health (Huang et al., 2005). Natural antioxidants that have demonstrated positive and useful effects on human health and their application are increasing due to their multiple roles in decreasing the harmful effects of oxidative stress (Mishra et al., 2012). Free radical scavenging activity through the DPPH method is one of the most popular methods to determine antioxidant activity in different plant extracts due to its simple and relatively fast procedures (Torre et al., 2019).

We determined that the FRSA of ethanol extracts of cultivars of C. annuum was from 1.66 (CA-05) to 7.27 (CA-01) mg TE/g DW (Fig. 4). This parameter for $C$. chinense and $C$. baccatum cultivars was from 1.45 (CC-06) to 8.21 (CC-05) $\mathrm{mg} \mathrm{TE} / \mathrm{g}$ DW and from 1.51 (CB-01) to 6.98 (CB-07) $\mathrm{mg} \mathrm{TE} / \mathrm{g} \mathrm{DW}$, respectively.

Hamed et al. (2019) found that antioxidant activity and content of ascorbic acid decreased in C. annuum cultivars after roasting. A decrease in the value of antioxidant activity was also observed and determined in boiled, roasted, and fried C. annuиm (Hwang et al., 2012).
A measurement of the reductive ability of Mo (VI) to transform into Mo (V) in the investigated extracts was implemented in this study. This is one of the assays of antioxidant capacities, along with others, through the formation of a phosphomolybdenum complex (Alam et al., 2013).

Ethanol extracts of the $C$. annuum cultivars exhibited molybdenum reducing powers in the extracts from 24.81 (CA-06) to 116.15 (CA-09) $\mathrm{mg} \mathrm{TE} / \mathrm{g} \mathrm{DW}$, in C. chinense cultivars from 27.9 (CC-01) to 106.06 (CC-07) $\mathrm{mg}$ TE/g DW and in C. baccatum cultivars from 37.23 (CB-04) to 198.21 (CB-07) $\mathrm{mg}$ TE/g DW (Fig. 5).

Olatunji and Afolayan (2019) determined the antioxidant capacity of ethanol and aqueous extracts of Capsicum annuum using the phosphomolybdenum method to be $65.55-77.66 \%$. In this case, it was difficult to compare the obtained data because of different expressions of units.

Phenolic compounds are secondary metabolites which synthesize in the plant tissues as the result of adaptation to different stress conditions and which play an important role as useful antioxidants in human life (Materska and Perucka, 2005). They demonstrate antioxidant, anti-allergic, anti-inflammatory, anticancer, antihypertensive, and antimicrobial activities (Daglia,

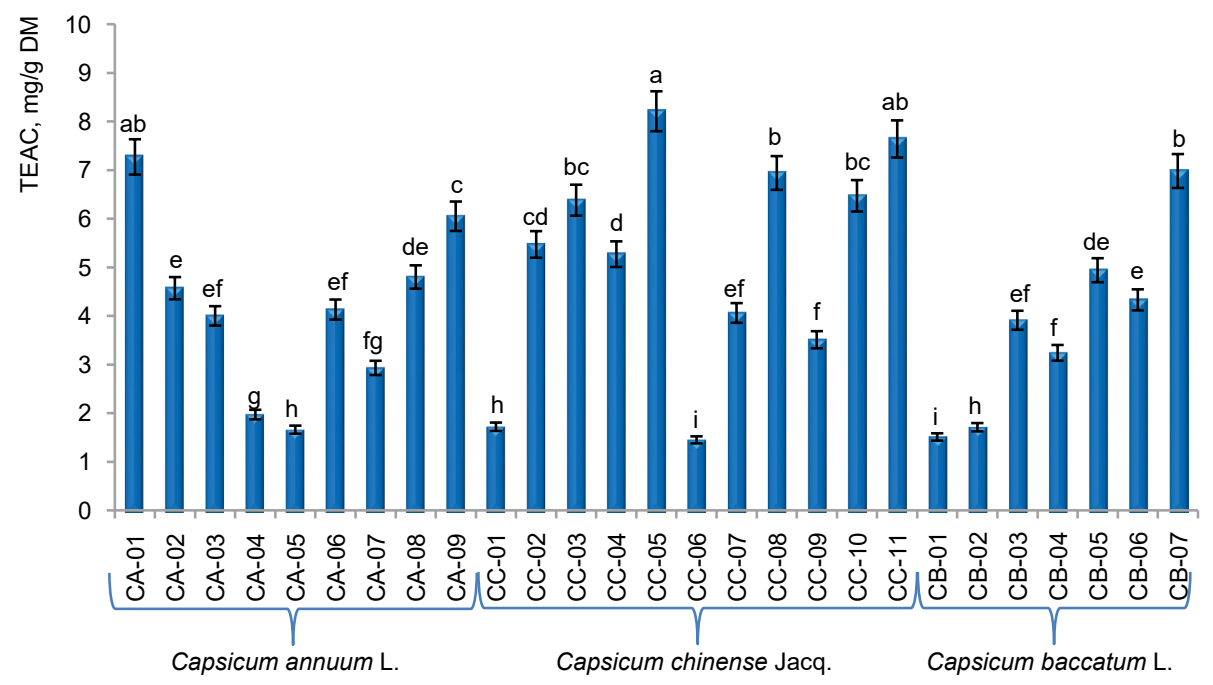

Fig. 4. Free radical scavenging activity of Capsicum spp. fruits evaluated using the DPPH method (different superscripts in each column indicate significant differences in the mean at $P<0.05$ ); TEAC - Trolox equivalent antioxidant capacity 


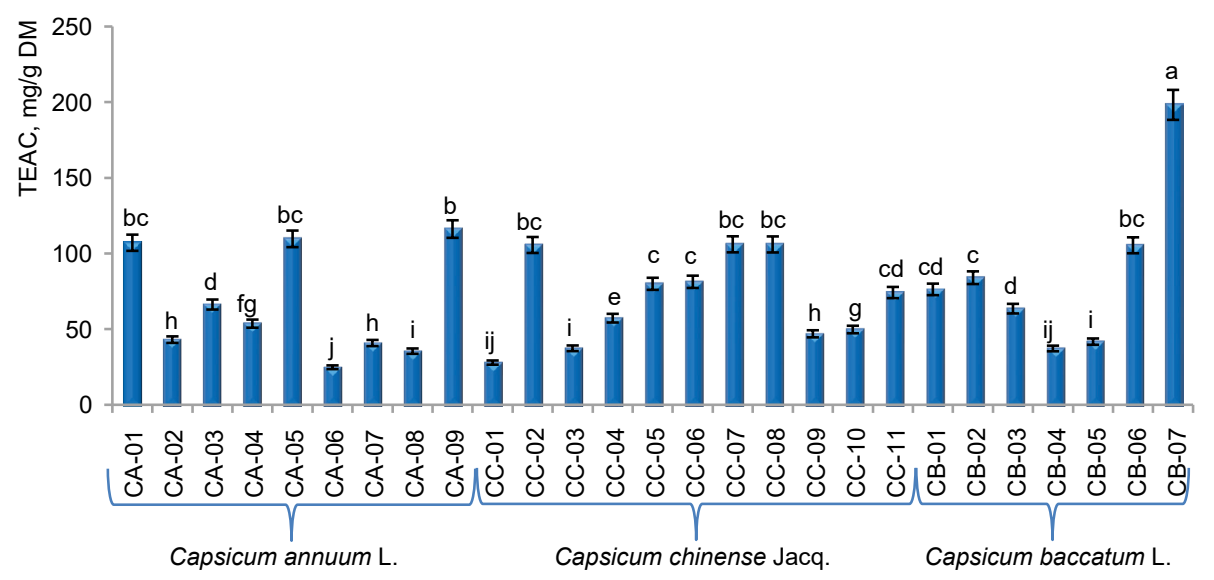

Fig. 5. Molybdenum reducing power of Capsicum spp. fruit extracts (different superscripts in each column indicate significant differences in the mean at $P<0.05)$; TEAC - Trolox equivalent antioxidant capacity

2012). Polyphenols can potentially prevent numerous diseases such as inflammation, cancer, type 2 diabetes mellitus, obesity, and cardiovascular and neurodegenerative diseases (Cory et al., 2018).

The total content of polyphenol compounds in our study was from 18.47 (CA-05) to 36.73 (CA-01) $\mathrm{mg}$ $\mathrm{GAE} / \mathrm{g} \mathrm{DW}$ in the $C$. annuum cultivars, from 11.36 (CC-02) to 35.10 (CC-06) $\mathrm{mg}$ GAE/g DW in the $C$. chinense cultivars, and from 10.13 (CB-03) to 38.69 (CB-07) $\mathrm{mg} \mathrm{GAE} / \mathrm{g}$ DW in the $C$. baccatum cultivars (Fig. 6).
According to Benbrahim et al. (2019), the mean value of TPC for Maleh spicy pepper was determined as $73.28 \mathrm{mg} \mathrm{GAE} / 100 \mathrm{~g}$. The maximal value, in this case, was $223.5 \mathrm{mg} \mathrm{GAE} / 100 \mathrm{~g}$, which was less than in our study. As reported by Bertão et al. (2016), TPC in ethanol extracts of $C$. annuum was $341.78 \mathrm{mg}$ GAE/g, of C. baccatum $156.76 \mathrm{mg} \mathrm{GAE} / \mathrm{g}$, and of $C$. chinense $107.98 \mathrm{mg} \mathrm{GAE} / \mathrm{g}$. Fresh fruits of $C$. chinense contained $200.17 \mathrm{mg}$ GAE/g of TPC (Sarpras et al., 2018). Comparing with this study, our TPC results showed lower values but we used dried raw. In another

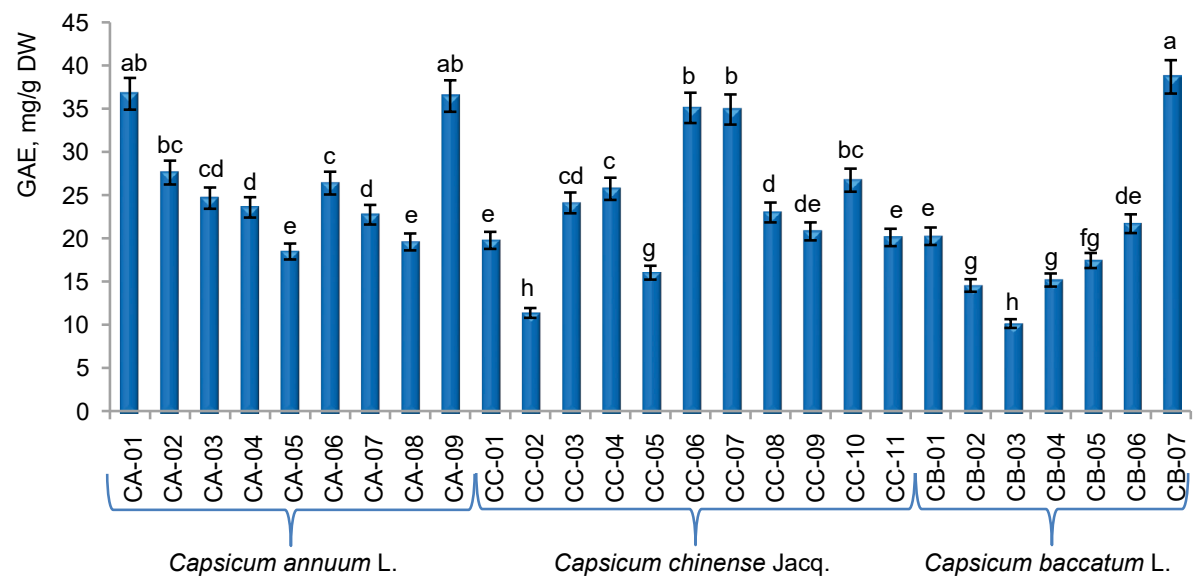

Fig. 6. Total polyphenol content in Capsicum spp. fruits (different superscripts in each column indicate significant differences in the mean at $P<0.05$ ); GAE - gallic acid equivalent 
study, TPC of cv. El Dorido was $38.4 \mathrm{mg} \mathrm{GAE} / 100 \mathrm{~g}$ DW, and of cv. Grande, $3.38 \mathrm{mg}$ GAE/g DW (Farhoudi et al., 2017). According to Medina-Juárez et al. (2012), TPC in extracts of five cultivars was from 59.34 to $154.30 \mathrm{mg} \mathrm{GAE} / 100 \mathrm{~g} \mathrm{FW}$, among which cv. Jalapeno had the lowest value. In our study, ethanol extracts of cv. Jalapeno showed a result of $18.47 \mathrm{mg}$ GAE/g DW and, also, had the lowest value among the studied cultivars of $C$. annuum. As reported by Zimmer et al. (2012), TPC in ethanol extracts was 180.08 mg GAE/g DW. Sim and Sil (2008) determined TPC in Capsicum annuum seed and pericarp to be 47.52 and $29.10 \mathrm{mg} \mathrm{GAE} / \mathrm{g}$, respectively. In a study by Sarpras et al. (2018), the content of TPC was determined to be $200.17 \mathrm{mg} \mathrm{GAE} / \mathrm{g}$. As reported by Olatunji and Afolayan (2019), TPC in cultivars of C. annuиm was from 200.70 to $272.47 \mathrm{mg} \mathrm{GAE} / \mathrm{g}$ in ethanol extracts and from 57.36 to $70.11 \mathrm{mg} \mathrm{GAE} / \mathrm{g}$ DW in water extracts. Hwang et al. (2012) compared the effects of cooking methods on the antioxidant properties of $C$. annuиm and determined the total polyphenol content in fresh raw material to be $148.66 \mathrm{mg}$ per $100 \mathrm{~g}$. The lowest content of polyphenols was identified in boiled samples (66.99-95.47 mg per $100 \mathrm{~g} \mathrm{FW})$. Loizzo et al. (2013) found TPC for C. annuum cultivars to be 116.7-195.5 mg chlorogenic acid equivalent per g extract. It should be noted that some review results of TPC could be obtained in mg GAE/100 g, evidently, due to the lower content of these compounds, whereas, in this study, we presented the results as $\mathrm{mg} \mathrm{GAE} / \mathrm{g}$ DW. Also, some reviews have represented their results from fresh, boiled, or roasted raw materials, which complicates any comparison of results.

According to Batra et al. (2017), among the phenolic compounds of $C$. annuum, flavonoids exhibited high antioxidant activity. Also, these compounds exhibited numerous biological activities such as antimicrobial, anti-inflammatory, analgesic, anti-allergic, and cytostatic, etc. (Koffi-Nevry et al., 2012). Flavonoids in the Capsicum species mainly accumulate in the peel, among which quercetin and luteolin are described as major representatives $(41 \%$ of total flavonoid content), and their concentration depends on ripening and environmental effects (Antonio et al., 2018).

The total content of flavonoids in the investigated ethanol fruit extracts of the $C$. annuum cultivars was from 12.56 (CA-05) to 24.72 (CA-01) mg QE/g DW, for the $C$. chinense cultivars from 8.16 (CC-02) to 24.31 (CC-06) mg QE/g DW and for the C. baccatum cultivars from 5.73 (CB-03) to 27.32 (CB-07) mg QE/g DW (Fig. 7). According to Bertão et al. (2016), the content of flavonoids in the fruit extracts of $C$. annuum was $123.56 \mathrm{mg} \mathrm{RE} / \mathrm{g}$, of C. baccatum $98.76 \mathrm{mg}$ $\mathrm{RE} / \mathrm{g}$, and of C. chinense $67.87 \mathrm{mg} \mathrm{GAE} / \mathrm{g}$ (RE - rutin equivalent). The fresh fruit of $C$. chinense had 41.61 $\mathrm{mg} \mathrm{QE} / \mathrm{g}$ of flavonoid content (Sarpras et al., 2018). In the study of Farhoudi et al. (2017) this parameter

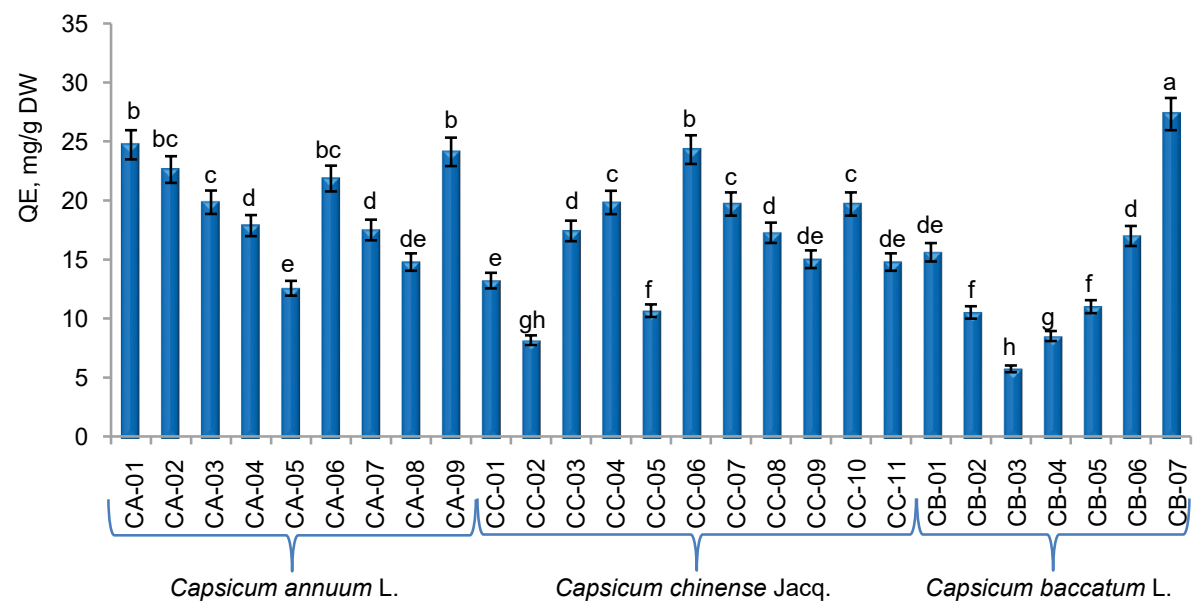

Fig. 7. Total flavonoid content in Capsicum spp. fruits (different superscripts in each column indicate significant differences in the mean at $P<0.05$ ); $\mathrm{QE}-$ quercetin equivalent 
was determined to be $9.93 \mathrm{mg} \mathrm{CAE} / 100 \mathrm{~g} \mathrm{DW}$ in $\mathrm{cv}$. Grande, $8.15 \mathrm{mg}$ CAE/100 g DW in cv. El Dorido and $3.03 \mathrm{mg} \mathrm{CAE} / 100 \mathrm{~g}$ DW in cv. Sayula. Medina-Juárez et al. (2012) found the content of flavonoids in the fresh fruit of five cultivars to be from 25.38 to $60.36 \mathrm{mg}$ QE/100 g. According to Loizzo et al. (2013), the total content of flavonoids in dried fried Capsicum cultivars was $11.5-15.0 \mathrm{mg} Q \mathrm{QE} / \mathrm{g}$, in dried Capsicum fruits $37.0-44.5 \mathrm{mg}$ QE/g, in fresh Capsicum fruits 46.0 $48.5 \mathrm{mg} \mathrm{QE} / \mathrm{g}$. The content of flavonoids in ethanol extracts of fruits of C. baccatum, as reported by Zimmer et al. (2012), was $34.36 \mathrm{mg} \mathrm{QE} / \mathrm{g} \mathrm{DW}$. The study of Zhuang et al. (2012) tested ethanol extracts of nine cultivars of $C$. annum and $C$. frutescens and the TPC was 1078.20-4992.40 $\mu \mathrm{g}$ GAE per g FW. Alam et al. (2018) determined the TPC and TFC of 0.159-0.430 $\mathrm{mg} \mathrm{GAE} / \mathrm{g}$ and $0.050-0.187 \mathrm{mg} \mathrm{QE} / \mathrm{g} \mathrm{DW}$, respectively, from the methanol extract of six Capsicum cultivars.

Together with flavonoids, the phenolic acids are also an important group of polyphenol compounds in human life that are distinguished as derivatives of benzoic acid and derivatives of cinnamic acid. The most abundant representative of this class of polyphenols is caffeic acid, which is present in most fruits (Manach et al., 2004). Among the phenolic acids in Capsicum cultivars gallic, caffeic, and chlorogenic acids were identified (Medina-Juárez et al., 2012). Zhuang et al. (2012) found gallic acid, 3,4-dihydroxybenzoic acid, catechin, vanillin, benzoic acid, salicylic acid, and luteolin in nine cultivars.

Determination of the total phenolic acid content showed that in the fruit extracts of $C$. annuum cultivars, TPAC accumulated from 3.34 (CA-08) to 9.47 (CA-09) $\mathrm{mg} \mathrm{CAE} / \mathrm{g} \mathrm{DW}$, in the $C$. chinense cultivars from 2.68 (CC-02) to 13.74 (CC-07) $\mathrm{mg} \mathrm{CAE} / \mathrm{g} \mathrm{DW}$ and in the $C$. baccatum cultivars from 2.24 (CB-03) to 9.00 (CB-07) mg QE/g DW (Fig. 8).

The cluster analysis was carried out earlier to study the similarity between the biological activity of different plant extracts and may be used as a useful tool for accession screening (Chaves et al., 2020; Dimitrijević et al., 2020; Ivanišová et al., 2017; Klymenko et al., 2019; Olatunji and Afolayan, 2019).

Hierarchical cluster analysis was used to evaluate the collected 27 cultivars of Capsicum spp. The TPC, TFC, TPAC, and antioxidant activities taken from DPPH assay and MRP assay were used as variables to establish the hierarchical cluster analysis. The dendrogram that was generated by the cluster analysis showed four well-defined groups (Fig. 9).

The first group consisted of three subgroups, while the second group consisted of two subgroups. These results show that these samples have similar phenolic components and antioxidant activities. Sample CB-07 (C. baccatum cv. Habanero Red Savina) was singled out as a separate group because it had the highest

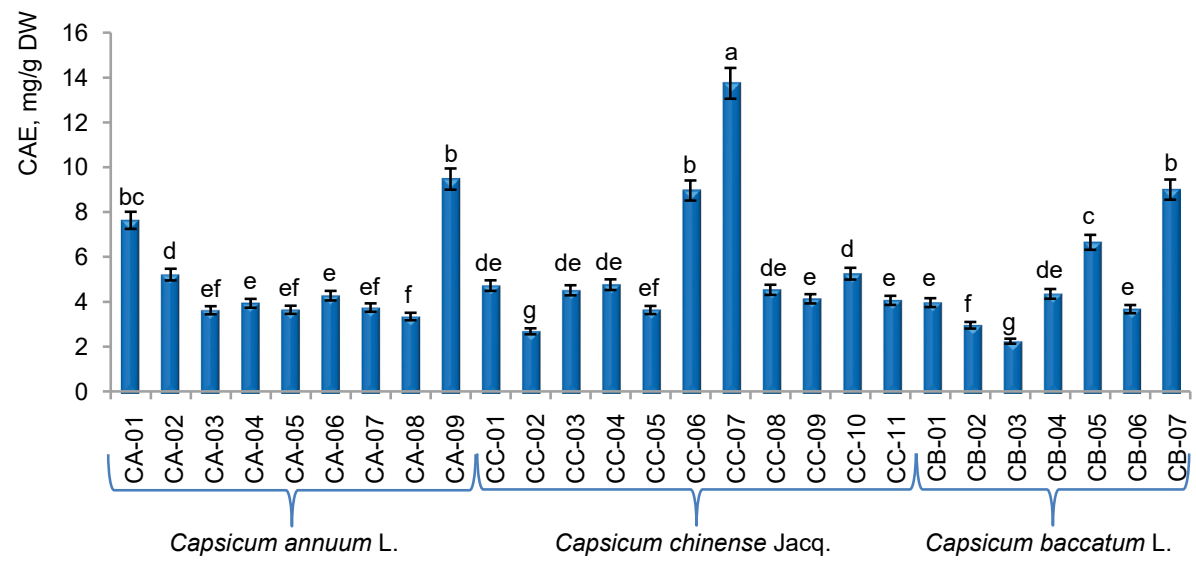

Fig. 8. The total phenolic acid content in Capsicum spp. fruits (different superscripts in each column indicate significant differences in the mean at $P<0.05$ ); CAE - caffeic acid equivalent 


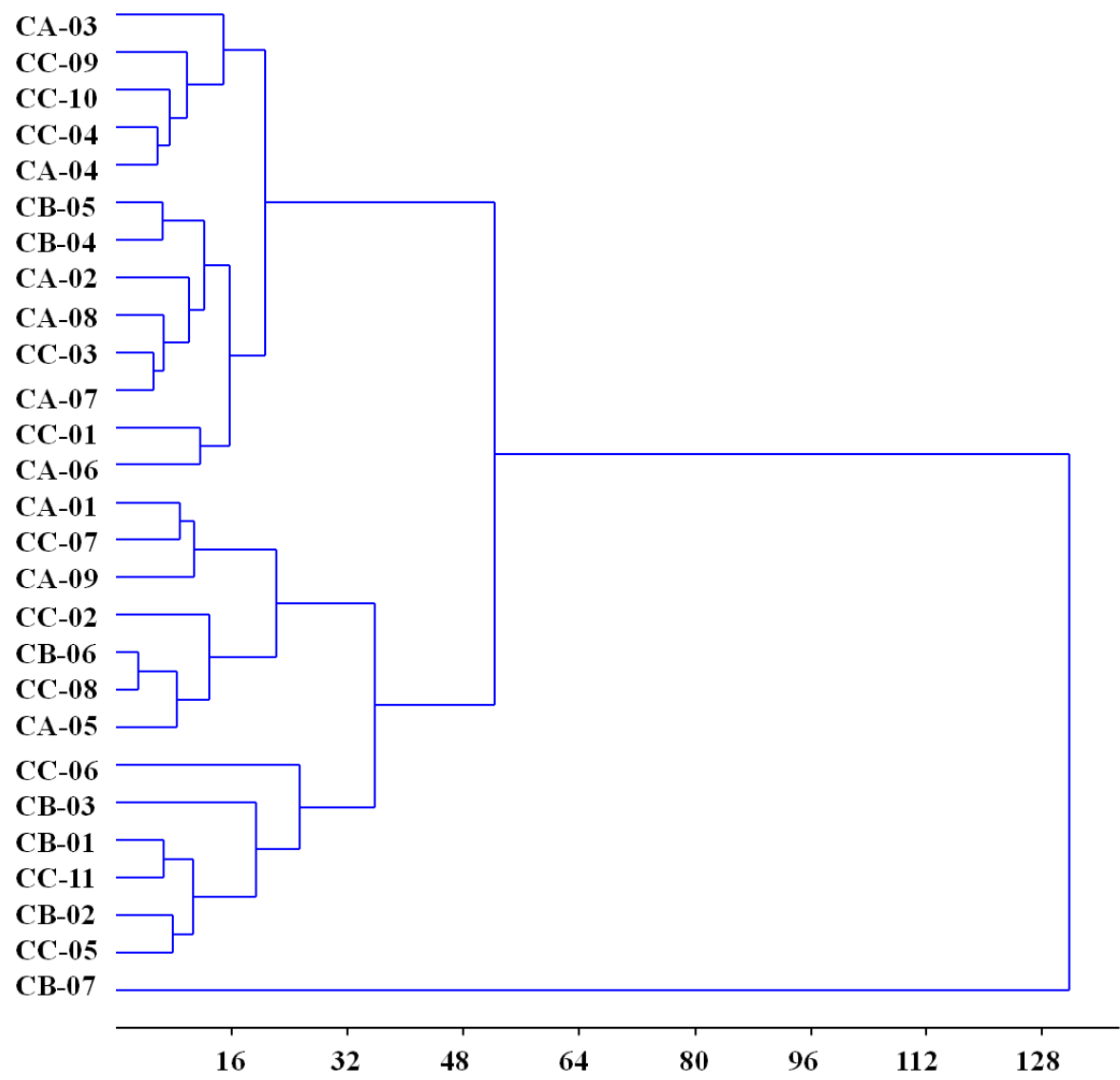

Fig. 9. Dendrogram from hierarchical cluster analysis of the antioxidant activity of 27 cultivars of Capsicum spp.

content of flavonoids, polyphenols, and the greatest antioxidant activity.

Correlation analysis of the investigated antioxidant parameters of the extracts of C. annuum, C. baccatum, and C. chinense is represented in Figure 10. A very strong correlation was found between the TPC and TPAC $(r=0.932)$, TPC and TFC $(r=0.921)$, and TPC and FRSA $(r=0.820)$ for the $C$. annuum extracts. A strong correlation was found between TFC and FRSA $(r=0.761)$, and TFC and TPAC $(r=0.755)$. Also, TPAC correlated with both FRSA $(r=0.744)$ and MRP $(r=0.648)$. In this case, the correlation was strong. A moderate correlation was determined between TPC and MRP $(r=0.480)$ in the $C$. annuum extracts. It should be noted that a weak correlation was detected between the FRSA and MRP $(r=0.279)$ and a very weak correlation between the TFC and MRP of the extracts $(r=0.159)$.

The study of plant extracts of $C$. baccatum showed a very strong correlation between the accumulation of flavonoids with the TPC $(r=0.982)$ and the MRP of the extracts $(r=0.908)$. The TPC of the investigated extracts also showed a very strong correlation with TPAC ( $r=0.839)$, and with MRP $(r=0.898)$. Strong relations were found between TPAC with flavonoids $(r=0.747)$ and with FRSA $(r=0.771)$. Also, TPC correlated with FRSA $(r=0.666)$. A moderate correlation existed between the MRP of the extracts and TPAC $(r=0.596)$. Also, this type of correlation was found between the FRSA and TFC (0.591) and between two species of AA. 

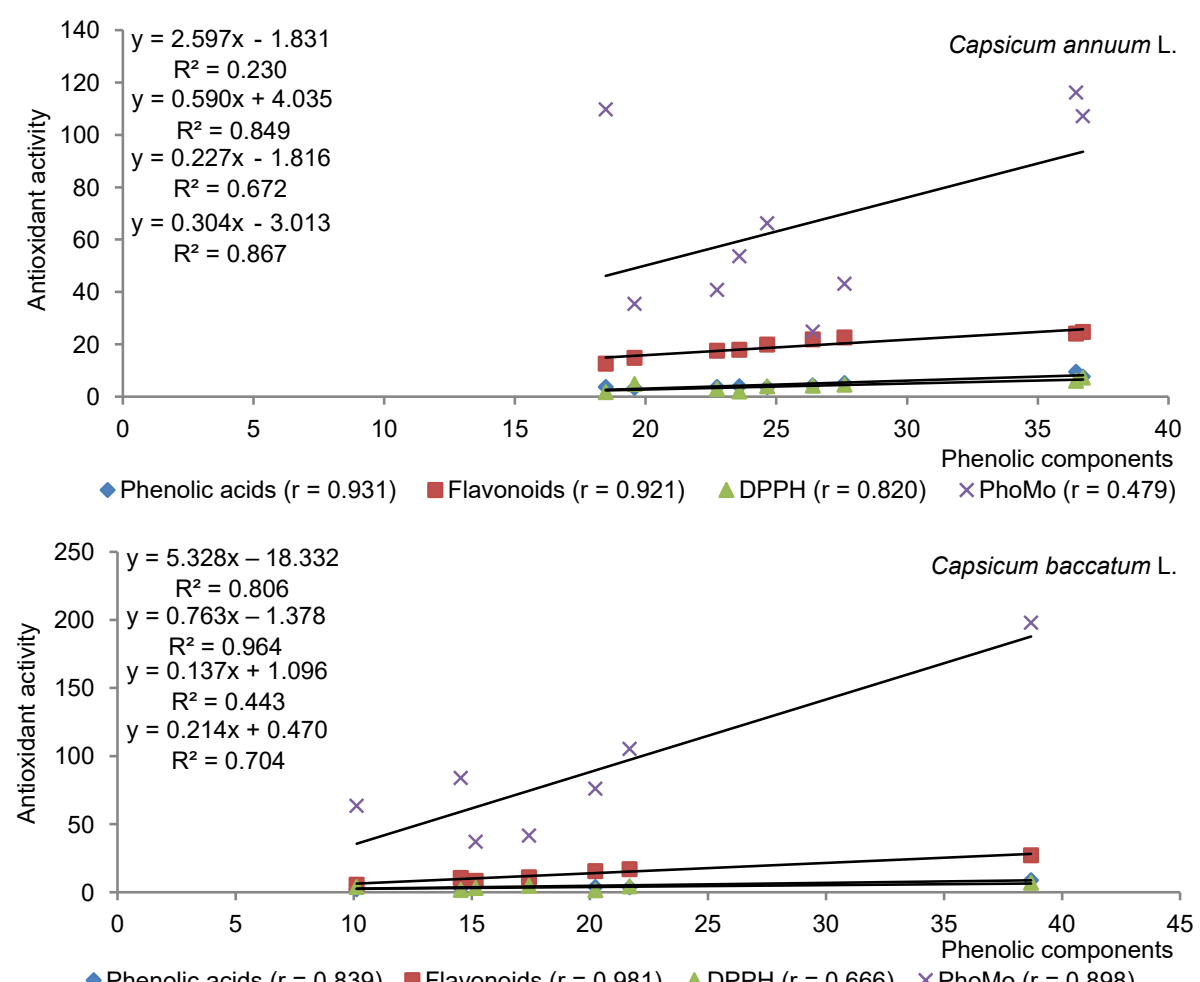

$\Delta$ Phenolic acids $(r=0.839) \quad$ Flavonoids $(r=0.981) \quad \triangle D P P H(r=0.666) \quad \times$ PhoMo $(r=0.898)$

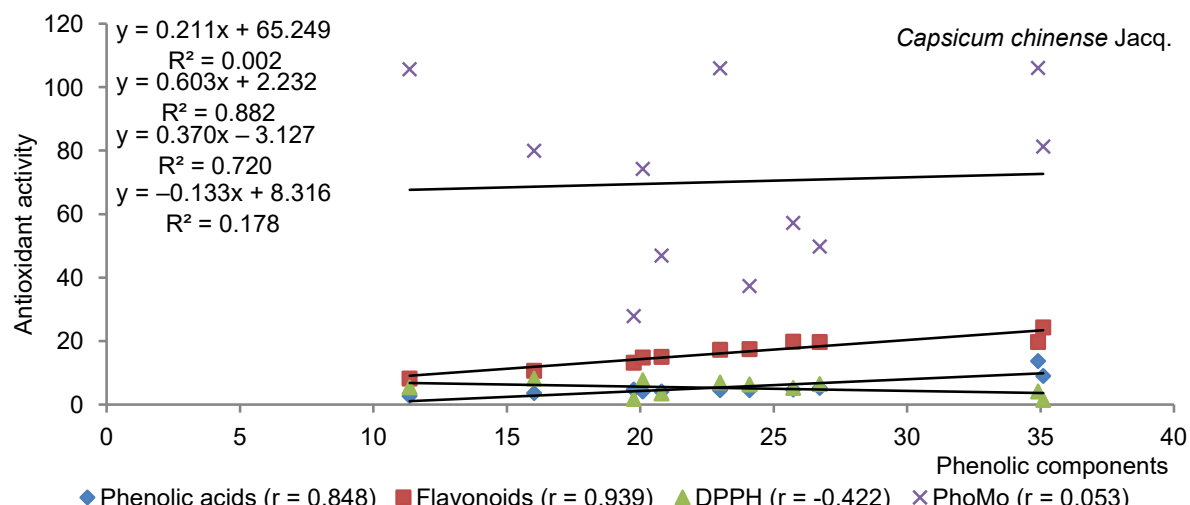

Fig. 10. Linear correlation between the phenolic components and antioxidant activity of Capsicum spp. cultivars

A correlation was found between the antioxidant parameters of the ethanol extracts of $C$. chinense. A very strong correlation was detected between TPC and TPAC $(r=0.848)$ and TFC $(r=0.939)$. A strong relation was determined between TPAC and TFC ( $r=$ $0.621)$. The obtained data demonstrated a weak correlation between MRP concerning TPAC $(r=0.323)$ and FRSA $(r=0.232)$ and a very weak relation between the TPC and MRP of the extracts. It should be noted that, in the rest of the cases, negative correlations between parameters were found.

As reported by Zhuang et al. (2012), a significant correlation was determined between the TPC and antioxidant activity of all the investigated cultivars of $C$. annuum and $C$. frutescens. In this case, the existing relations between TPC and MRP and FRSA were 
$r=0.883$ and $r=0.850$, respectively. As the authors noted, the chemistry behind these methods is based on the same redox ability. The results obtained by Materska (2014) allowed a correlation to be found between TPC and antioxidant activity in the C. annuum extracts. Hamed et al. (2019) studied the relations between TPC, TFC, and ascorbic acid accumulation, which can be associated with antioxidant activity, and found a weak positive correlation between TPC and TFC with FRSA and another method used to determine antioxidant activity (ABTS assay). This report contrasted with our results because we found a very strong correlation between TPC and TFC, and the association between TPC and antioxidant activity in our study was stronger (apart from in the $C$. chinense cultivars). Farhoudi et al. (2017) found a very strong correlation between TPC and reducing power $(r=0.91)$, between TPC and FRSA $(r=0.81)$, and between TFC with reducing power $(r=0.90)$ and FRSA $(r=0.89)$. In the current study, we had a strong correlation between TFC and MRP in the C. baccatum extracts, while in $C$. chinense these relations were negative. Hwang et al. (2012) identified a very strong correlation between TPC and antioxidant activity of cooked $C$. annuum using the DPPH method $(r=0.991)$. Medina-Juárez et al. (2012) determined a very strong correlation between different flavonoids and FRSA $(r=0.881-0.954)$.

\section{CONCLUSIONS}

The parameters of antioxidant activity, such as the content of total polyphenol compounds, flavonoids, and phenolic acids in ethanol fruit extracts of Capsicum annuum, C. baccatum, and C. chinense, were used in this study. Based on the results, the highest values of total polyphenol, flavonoid, phenolic acid content, and molybdenum reducing power were exhibited by extracts of 'Habanero Red Savina' cultivar (C. baccatum). The maximal value of antioxidant activity found using the DPPH method was in an extract of cv. Fidalgo Roxa (C. chinense). The polyphenol compounds of the $C$. annuum and C. baccatum cultivars were associated with antioxidant activity. The variability of antioxidant parameter values was high between cultivars within these species. The assessment of Capsicum cultivars using selected biochemical parameters demonstrated that these plants are potent sources of antioxidants which are important in human nutrition and good health.

\section{REFERENCES}

Alam, A. M., Siazwanie, F. N., Mahmod, H. N., Badaluddin, A. N., Mustafa, A. K., Alias, N., ..., Prodhan, A. M. (2018). Evaluation of antioxidant compounds, antioxidant activities and capsaicinoid compounds of Chili (Capsicum sp.) germplasm available in Malaysia. J. Appl. Res. Med. Aromat. Plants, 9, 46-54. https://doi. org/10.1016/j.jarmap.2018.02.001

Alam, Md. N., Bristi, N. J., Rafiguzzaman, Md. (2013). Review on in vivo and in vitro methods evaluation of antioxidant activity. Saudi Pharm. J., 21, 143-152. http:// dx.doi.org/10.1016/j.jsps.2012.05.002

Aliu, S., Rusinovci, I., Fetahu, S., Kaçiu, S., Zeka, D. (2017). Assessment of morphological variability and chemical composition of some local pepper (Capsicum annuum L.) populations on the area of Kosovo. Acta Agric. Slov., 109, 205-213. https://doi.org/10.14720/ aas.2017.109.2.05

Antonio, A. S., Weidemann, S. M., Veiga Junior, V. F. (2018). The genus Capsicum: a phytochemical review of bioactive secondary metabolites. RSC Adv., 8, 25767-25784. https://doi.org/10.1039/c8ra02067a

Antonious, G. F., Lobel, L., Kochhar, T., Berke, T., Jarret, R. L. (2009). Antioxidants in Capsicum chinense: variation among countries of origin. J. Environ. Sci. Health, Part B, 44, 621-626. https://doi.org/10.1080/0360 1230903000727

Batra, G., Gortzi, O., Lalas, S. I., Galadi, A., Alibade, A., Nanos, G. D. (2017). Enhanced antioxidant activity of Capsicum annuum L. and Moringa oleifera L. extracts after encapsulation in microemulsions. Chem. Eng. J., 1, 15. https://doi.org/10.3390/chemengineering 1020015

Benbrahim, N., Mentag, R., Elghzaoui, Y., Triqui, A. Z., Gmouh, S., ES-Safi, N., ..., Taghouti, M. (2019). Fruits morphological qualitative traits, biochemical components and pungency strength of spicy pepper from Maleh Valley in Morocco. J. Plant Sci., 7, 29-43. https:// doi.org/10.13189/ujps.2019.070301

Bertão, R. M., Moraes, M. K., Palmieri, D. A., Silva Pereira, L., da Silva Gonçalves, M. R. (2016). Cytotoxicity, genotoxicity and antioxidant activity of extracts from Capsicum spp. Res. J. Med. Plant, 10, 265-275. https:// doi.org/10.3923/rjmp.2016

Chaves, N., Santiago, A., Alías, J. C. (2020). Quantification of the antioxidant activity of plant extracts: analysis 
of sensitivity and hierarchization based on the method used. Antioxidants, 9, 76. https://doi.org/10.3390/antiox 9010076

Cory, H., Passarelli, S., Szeto, J., Tamez, M., Mattei, J. (2018). The role of polyphenols in human health and food system: a mini-review. Front. Nutr., 5, 87. https:// doi.org/10.3389/fnut.2018.00087

Daglia, M. (2012). Polyphenols as antimicrobial agents. Curr. Opin. Biotechnol., 23, 174-181. https://10.1016/j. copbio.2011.08.007

Dimitrijević, M. V., Mitić, V. D., Ranković, G. Ž., Miladinović, D. L. (2020). Survey of antioxidant properties of barberry: a chemical and chemometric approach. Anal. Chem. Symp. Ser., 53, 671-682. https://doi.org/10 $.1080 / 00032719.2019 .1663862$

Farhoudi, R., Mehrnia, M. A., Lee, D.-J. (2017). Antioxidant activities and bioactive compounds of five Jalapeno peppers (Capsicum annuum) cultivars. Nat. Prod. Res., 33, 871-874. https://doi.org/10.1080/14786419.2017.14 10801

Farmakopea Polska (1999). The Polish Farmaceutical Society. Available at: http://www.ptfarm.pl/?pid=1\&langu age $=$ en

Gomez-Garcia, R. M., Ochoa-Alejo, N. (2013). Biochemistry and molecular biology of carotenoid biosynthesis in Chili Peppers (Capsicum spp.). Int. J. Mol. Sci., 14, 19025-19053. https://doi.org/10.3390/ijms140919025

Guillen, N. G., Tito, R., Mendoza, N. G. (2018). Capsaicinoids and pungency in Capsicum chinense and Capsicum baccatum fruits. Pesq. Agropec. Trop., 48, 3, 237-244. https://doi.org/10.1590/1983-40632018v4852334

Hamed, M., Kalita, D., Bartolo, M. E., Jayanty, S. S. (2019). Capsaicinoids, polyphenols and antioxidant activities of Capsicum annuum: comparative study of the effect of ripening stage and cooking methods. Antioxidants, 8, 364. https://doi.org/10.3390/antiox8090364

Hernández-Ortega, M., Ortiz-Moreno, A., Hernández-Navarro, M. D., Chamorro-Cevallos, G., Dorantes-Alvarez, L., Necoechea-Mondragón, H. (2012). Antioxidant, antiniciceptive, and anti-inflammatory effects of carotenoids extracted from dried pepper (Capsicum annuиm L.). J. Biomed. Biotechnol., 2012, 524019. https://doi. org/10.1155/2012/524019

Huang, D., Ou, B., Prior, R. L. (2005). The chemistry behind antioxidant capacity assays. J. Agric. Food Chem., 53, 1841-1856. https://doi.org/10.1021/jf030723c

Hwang, I. G., Shin, Y. J., Lee, S., Lee, J., Yoo, S. M. (2012). Effect of different cooking methods on antioxidant properties of red pepper (Capsicum annuum L.). Prev.
Nutr. Food Sci., 17, 286-292. http://dx.doi.org/10.3746/ pnf.2012.17.4.286

Ivanišová, E., Grygorieva, O., Abrahamová, V., Schubertova, Z., Terentjeva, M., Brindza, J. (2017). Characterization of morphological parameters and biological activity of jujube fruit (Ziziphus jujuba Mill.). J. Berry Res., 7, 249-260. https://doi.org/10.3233/JBR-170162

Kantar, B. M., Anderson, J. E., Lucht, S. A., Mercer, K., Bernau, V., Case, K. A., ..., Baumer, D. J. (2016). Vitamin variation in Capsicum spp. provides opportunities to improve nutritional value of human diets. PloS One, 11, e0161464. https://doi.org/10.1371/journal.pone.0161464

Kim, E.-H., Lee, S.-Y., Baek, D.-Y., Park, S.-Y., Lee, S. G., Ryu, T.-H., ..., Oh, S.-W. (2019). A comparison of the nutrient composition and statistical profile in red pepper fruits (Capsicum annuum L.) based on genetic and environmental factors. Appl. Biol. Chem., 62, 48. https://doi. org/10.1186/s13765-019-0456-y

Klymenko, S., Kucharska, A. Z., Sokół-Łętowska, A., Piórecki, N. (2019). Antioxidant activities and phenolic compounds in fruits of cultivars of cornelian cherry (Cornus mas L.). Agrobiodiv. Impr. Nut. Health Life Qual., 3, 484-499. https://doi.org/10.15414/agrobiodiversity.2019.2585-8246.484-499

Koffi-Nevry, R., Kouassi, K. C., Nanga, Z. Y., Koussémon, M., Loukou, G. Y. (2012). Antibacterial activity of two bell pepper extracts: Capsicum annuum L. and Capsicum frutescens. Int. J. Food Prop., 15, 961-971. https:// doi.org/10.1080/10942912.2010.509896

Loizzo, M. R., Pugliese, A., Bonesi, M., De Luca, D., O'Brien, N., Menichini, F., Tundis, R. (2013). Influence of drying and cooking process on the phytochemical content, antioxidant and hypoglycaemic properties of two bell Capsicum annuum L. cultivars. Food Chem. Toxicol., 53, 392-401. http://dx.doi.org/10.1016/j. fct.2012.12.011

Loizzo, M. R., Pugliese, A., Bonesi, M., Menichini, F., Tundis, R. (2015). Evaluation of chemical profile and antioxidant activity of twenty cultivars from Capsicum annuum, Capsicum baccatum and Capsicum chinense: a comparison between fresh and processed peppers. LWT - Food Sci. Technol., 64, 623-631. http://dx.doi. org/10.1016/j.lwt.2015.06.042

Manach, C., Scalbert, A., Morand, Ch., Rémésy, Ch., Jiménez, L. (2004). Polyphenols: food sources and bioavailability. Am. J. Clin. Nutr., 79, 727-747. https://doi. org/10.1093/ajcn/79.5.727

Materska, M. (2014). Bioactive phenolics of fresh and freezedried sweet and semi-spicy pepper fruits (Capsicum 
Mňahončáková, E., Vergun, O., Grygorieva, O., Sedláčková, V. H., Ivanišová, E., Šramková, K. F., Hrúzová, M., Brindza, J. (2021). Evaluation of the antioxidant potential of Capsicum annuum L., C. baccatum L. and C. chinense Jacq. cultivars. Acta Sci. Pol. Technol. Aliment., 20(2), 223-236. http://dx.doi.org/10.17306/J.AFS.2021.0941

annuum L.). J. Funct. Foods, 7, 269-277. https://doi. org/10.1016/j.jff.2014.02.002

Materska, M., Perucka, I. (2005). Antioxidant activity of the main phenolic compounds isolated from hot pepper fruit (Capsicum annuum L.). J. Agric. Food Chem., 53, 1750-1756. https://doi.org/10.1021/jf035331k

Medina-Juárez, L. A., Molina-Quijada, D. M. A., Toro-Sánchez, C. L. D., Gonzáles-Aguilar, G. A., Gámez-Meza, N. (2012). Antioxidant activity of peppers (Capsicum annuum L.) extracts and characterization of their phenolic constituents. Interciencia, 37, 588-593.

Minguez-Mosquera, M. I., Hornero-Mendez, D. (1994). Comparative study of the effect of paprika processing on the carotenoids in peppers (Capsicum annuum) of the Bola and Agridulce varieties. J. Agric. Food Chem., 42, 1555-1560. https://doi.org/10.1021/jf00043a031

Mishra, K., Ojha, H., Chaundhary, N. K. (2012). Estimation of antiradical properties of antioxidants using DPPH assay: a critical review and results. Food Chem., 130, 1036-1043. https://doi.org/10.1016/j.foodchem.2011.07.127

Mňahončáková, E., Valný, P., Horčinová Sedláčková, V. (2020). Morphological features of fruits of various species of chilli peppers. Agrobiodiv. Impr. Nut. Health Life Qual., 4, 159-175. https://doi.org/10.15414/agrobiodiversity.2020.2585-8246.159-175

Nadeem, M., Anjum, F. M., Khan, M. R., Saeed, M., Riaz, A. (2011). Antioxidant potential of Bell Pepper (Capsicum annuum L.) - a review. Pakistan J. Food Sci., 21, $45-51$.

Olatunji, T. L., Afolayan, A. J. (2019). Comparative quantitative study of phytochemical contents and antioxidant activities of Capsicum annuum L. and Capsicum frutescens L. Sci. World J., 4705140. https://doi. org/10.1155/2019/4705140

Perucka, I., Materska, M. (2007). Antioxidant vitamin contents of Capsicum annuum fruit extracts of affected by proccessing and varietal factors. Acta Sci. Pol. Technol. Aliment., 6, 67-74.

Prieto, P., Pineda, M., Aguilar, M. (1999). Spectrophotometric quantitation of antioxidant capacity through the formation of a phosphomolybdenum complex: specific application to the determination of vitamin E. Anal. Biochem., 269, 337-241. https://doi.org/10.1006/ abio.1999.4019

Ribes-Moya, A. M., Pereira, L., Guijarro-Real, C., Raigon, D. M., Fita, A. M., Rodríguez-Burruezo, A. (2014). Mineral content of Capsicum pepper landraces: effect of the genotype and the ripening stage. Bull. UASVM
Horticulture, 71，359-360. https://doi.org/10.15835/ buasvmcn-hort:10679

Rodríguez-Burruezo, A., Mas-Gonsález, C., Nuez, F. (2010). Carotenoid composition and vitamin A value in Aji (Capsicum baccatum L.) and Rocoto (C. pubescens R. \& P.), 2 pepper species from the Andean region. J. Food Sci., 75, 446-453. https://doi.org/10.1111/j.17503841.2010.01795.x

Sanati, S., Razavi, B. M., Hosseinzadeh, H. (2018). A review of the effects of Capsicum annum L. and its constituent, capsaicin, in metabolic syndrome. Iran J. Basic Med. Sci., 21, 439-448. https://doi.org/10.22038/ IJBMS.2018.25200.6238

Sánchéz-Moreno, C., Larrauri, A., Saura-Calixto, F. (1998). A procedure to measure the antioxidant efficiency of polyphenols. J. Sci. Food Agric., 76, 270-276. https://doi. org/10.1002/(SICI)1097-0010(199802)76:2<270::AIDJSFA 945>3.0.CO;2-9

Sarpras, M., Chhapekar, S. S., Ahmad, I., Abraham, S. K., Ramchiary, N. (2018). Analysis of bioactive components in Ghost chili (Capsicum chinense) for antioxidant, genotoxic, and apoptotic effects in mice. Drug Chem. Toxicol., 43, 182-191. https://doi.org/10.1080/0 1480545.2018.1483945

Shafii, Z. A., Basri, M., Malek, E. A., Ismail, M. (2017). Phytochemical and antioxidant properties of Manilkara zapota (L.) P royen fruit extracts and its formulations for cosmeceutical application. Asian J. Plant Sci., 7, 29-41.

Sim, K. H., Sil, H. Y. (2008). Antioxidant activities of red pepper (Capsicum annuum) pericarp and seed extracts. Int. J. Food Sci. Technol., 43, 1813-1823. https://doi. org/10.1111/j.1365-2621.2008.01715.x

Singleton, V. L., Rossi, J. A. (1965). Colorimetry of total phenolics with phosphomolybdic-phosphotungstic acid reagent. Am. J. Enol. Vitic., 6, 144-158.

Torre, M. P., Cavero, R. Y., Calvo, M. I., Vizmanos, J. L. (2019). A simple and a reliable method to quantify antioxidant activity in vivo. Antioxidants, 8,142 . https://doi. org/10.3390/antiox 8050142

Tundis, R., Loizzo, M. R., Menichini, F., Bonesi, M., Contorti, F., Statti, G., Luca, D. D., de Cindio, B. (2011). Comparative study on the chemical composition, antioxidant properties and hypoglycaemic activities of two Capsicum annuum L. cultivars (Acuminatum small and Cerasiferum). Plant Foods Hum. Nutr., 66, 261-269. https://doi.org/10.1007/s11130-011-0248-y

Wesołowska, A., Jadczak, D., Grzeszczuk, M. (2011). Chemical composition of the pepper fruit extracts of hot cultivars Capsicum annum L. Acta Sci. Pol. Hortor., $10,171-184$ 
Mňahončáková, E., Vergun, O., Grygorieva, O., Sedláčková, V. H., Ivanišová, E., Šramková, K. F., Hrúzová, M., Brindza, J. (2021). Evaluation of the antioxidant potential of Capsicum annuum L., C. baccatum L. and C. chinense Jacq. cultivars. Acta Sci. Pol. Technol. Aliment., 20(2), 223-236. http://dx.doi.org/10.17306/J.AFS.2021.0941

Zhuang, Y., Chen, L., Sun, L., Cao, J. (2012). Bioactive characteristics and antioxidant activities of nine peppers. J. Funct. Foods, 4, 331-338. https://doi.org/10.1016/j. jff.2012.01.001

Zimmer, A. R., Leonardi, B., Miron, D., Schapolval, E., Oliveira, J. R., Gosmann, G. (2012). Antioxidant and anti-inflammatory properties of Capsicum baccatum: from traditional use to scientific approach. J. Ethnopharmacol., 139, 228-233. https://doi.org/10.1016/j. jep.2011.11.005 